\title{
14. SOME PRELIMINARY RESULTS ON THE HIGHER WEIGHT HYDROCARBONS AND FATTY ACIDS IN THE DEEP SEA DRILLING PROJECT CORES. LEGS $5-7^{1}$
}

\author{
Bernd R. Simoneit and A. L. Burlingame \\ Space Sciences Laboratory \\ University of California, Berkeley
}

The following report describes the preliminary organic analyses performed on the DSDP cores (Legs 5 to 7 ) at the Space Sciences Laboratory, University of California, Berkeley. In order to get a general idea of what organic compound families and their respective molecular weight distributions are present in these cores the following approach was initiated. The small (approximately 1 to 2 grams) samples remaining from the organic carbon analyses of Legs 5 through 7 were solvent extracted and the extract residues subjected to high resolution mass spectrometry. Based on the findings from this initial survey the experimental procedures for the larger (approximately 100 grams) samples were modified and applied as discussed later in this report.

The small samples, which were received as dried powders, were extracted-usually for five days-with $3: 1$ benzene/methanol (redistilled nanograde purity) in a Soxhlet extractor. The solvent was removed from the extract under water aspirator vacuum and the residue further fractionated to remove the large quantities of inorganic salts. The bulk of the organics were removed from the residue by solution in heptane and weighed after solvent removal (see Table 1). The residue was then treated with methanol to dissolve the more polar organics and, of course, large amounts of inorganic salts (see Table 1). It should be noted that in samples where the methanol solubles are high, a large salt residue remained insoluble. All the heptane extracts and some of the methanol extracts were subjected to high resolution mass spectrometry. These analyses were carried out on a GEC-AEI MS-902 mass spectrometer online to an XDS Sigma 7 Computer (described by Burlingame, 1968 and 1969, and Burlingame et al., 1970). The samples were introduced via a direct inlet probe into the ion source, operated at the following conditions: resolution 10,000 to 12,000 ; ionizing current $500 \mu \AA$; ionizing voltage $50 \mathrm{eV}$; and temperature 200 to $220^{\circ} \mathrm{C}$. The scan rate was 16 seconds per decade with a clock rate of $24 \mathrm{kHz}$. Multiple scans were taken during each analysis and then sum averaged together during data reduction. Selected high resolution mass spectral data are presented as heteroatomic plots

\footnotetext{
${ }^{1}$ Research supported by the Oceanography Section, National Science Foundation, NSF Grant GA-24214.
}

(Burlingame and Smith, 1968) in various figures in the text. The low resolution mass spectra were also determined on a GEC-AEI MS-902 mass spectrometer. Gas chromatography was carried out using a PerkinElmer Model 900 gas chromatograph with a flame ionization detector and operating conditions as stated in the respective figure legends.

The methanol extracts consist mainly of inorganic salts (mostly chlorides), water, low molecular-weight hydrocarbons and fatty acids. The largest skeleton observed was $\mathrm{C}_{15}$ for the alkanes and $\mathrm{C}_{12}$ for the acids.

The heptane extracts are quite diverse, the most predominant compounds being hydrocarbons in all cases, with minor amounts of mono- and dioxygenated species present and trace amounts of polyoxygenated compounds. No nitrogen or sulfur containing species were detected above background in these total extracts.

The general formula for organics as hydrocarbons, alcohols and acids is $\mathrm{C}_{n} \mathrm{H}_{2 n-z} \mathrm{O}_{m}$, where $\mathrm{n}$ is the number of carbons in the molecule, $\mathrm{z}$ is a measure of the degree of unsaturation of the molecule, and $\mathrm{m}$ is the number of oxygen heteroatoms. In all the samples analyzed the most commonly encountered degrees of unsaturation (see Table 2) are zero (deduced from the fragment ions mainly), one and four, with less of two, three and five, and a trace of seven but no six. In other words, there is an abundance of more saturated systems with lesser amounts of polycyclic systems, but virtual absence of higher weight condensed aromatic systems (as found in some shale oils and petroleums).

The major compound series are listed with the respective source cores in Table 1 . Some of the more interesting and promising findings follow in greater detail.

\section{SMALLER SAMPLE ANALYSES}

\section{Leg 6, Hole 52.0-3-6}

The saturated alkanes $\mathrm{C}_{\mathrm{n}} \mathrm{H}_{2 \mathrm{n}+2}$ and $\mathrm{C}_{\mathrm{n}} \mathrm{H}_{2 n}$ range from $\mathrm{n}=9$ to 19 , with minor amounts of the $\mathrm{C}_{\mathrm{n}} \mathrm{H}_{2 \mathrm{n}-2}$ series ranging from $n=10$ to 20 . The only more aromatized species found is $\mathrm{C}_{18} \mathrm{H}_{24}$ (possible Structure II) which 
TABLE 1

DSDP Core Extracts Legs 5-7

\begin{tabular}{|c|c|c|c|c|c|}
\hline Sample ${ }^{\mathrm{a}}$ & $\begin{array}{l}\text { Per Cent } \\
\text { Organic } \\
\text { Carbon }\end{array}$ & $\begin{array}{c}\text { PPM } \\
\text { Heptane } \\
\text { Extract }\end{array}$ & $\begin{array}{c}\text { PPM } \\
\text { Methanol } \\
\text { Extract }\end{array}$ & $\begin{array}{l}\text { Approximate } \\
\text { Age }^{\mathrm{b}}\end{array}$ & $\begin{array}{c}\text { Compound Types } \\
\text { Found }^{\mathrm{c}}\end{array}$ \\
\hline \multicolumn{6}{|l|}{ Leg 5} \\
\hline $32-6-3$ & 0.28 & 282 & 6900 & L. Pliocene & $A+C$ \\
\hline $32-12-3$ & 0.05 & 254 & 2040 & U. Oligocene & $A+C$ \\
\hline $33-5-3$ & 0.43 & 372 & 1890 & L. Pliocene & $A, C+T$ \\
\hline $34-4-4$ & 0.59 & 259 & 4000 & L. Pliocene & $\mathrm{A}, \mathrm{C}+\mathrm{T}$ \\
\hline $34-5-4$ & 0.65 & 458 & 5640 & L. Pliocene & $A+C$ \\
\hline $34-10-1$ & 0.27 & 434 & 3340 & M. Miocene & $\mathrm{A}, \mathrm{C}+\mathrm{T}$ \\
\hline $35-6-3$ & 0.39 & 360 & 4660 & Pleistocene & $A+C$ \\
\hline $36-8-0$ & 0.35 & 110 & 770 & U. Pliocene & $A+C$ \\
\hline $36-11-0$ & 0.32 & 960(hi) & 7240 & L. Pliocene & $A+C$ \\
\hline $36-12-0$ & 0.25 & 146 & 3700 & U. Miocene & $\mathrm{A}, \mathrm{C}+\mathrm{T}$ \\
\hline $37-3-0$ & 0.20 & 212 & 12,300 & L. Pliocene & $A+C$ \\
\hline $38-5-0$ & 0.22 & 7 & 5140 & $?$ & $A+C$ \\
\hline $40-15-5$ & 0.02 & $<10$ & 8900 & L. Eocene & \\
\hline $42-5-0$ & 0.11 & 670 & $\sim 20,400$ & L. Oligocene & $A+C$ \\
\hline $42-10-0$ & 0.15 & 760 & 12,700 & L. Eocene & $A+C$ \\
\hline $42-10-2$ & - & 534 & 12,050 & L. Eocene & \\
\hline \multicolumn{6}{|l|}{ Leg 6} \\
\hline $47.0-1-4$ & 0.30 & 156 & 1600 & Pleistocene & $A+C$ \\
\hline $47.2-10-5$ & 0.10 & 36 & 1360 & L. Paleocene & $A+C$ \\
\hline $49.0-1-3$ & 0.08 & 145 & 6370 & L. Pleistocene & $\mathrm{A}, \mathrm{C}, \mathrm{S}+\mathrm{T}$ \\
\hline $50.1-1-2$ & 0.13 & 85 & 1670 & Pleistocene & $A+C$ \\
\hline $50.1-3-6$ & 0.08 & 263 & 865 & $?$ & $A+C$ \\
\hline $51.0-1-6$ & 0.12 & 88 & 1920 & Miocene & $\mathrm{A}, \mathrm{C}, \mathrm{S}+\mathrm{T}$ \\
\hline $52.0-3-6$ & 0.04 & 118 & 1530 & Paleocene & $\mathrm{A}, \mathrm{C}, \mathrm{S}+\mathrm{T}$ \\
\hline $53.1-2-6$ & 0.08 & 288 & 9160 & U. Miocene & $A+C$ \\
\hline $53.2-1-5$ & 0.08 & 75 & 3550 & U. Miocene & $A+C$ \\
\hline $55.0-6-5$ & 0.09 & $<1$ & 6900 & M. Miocene & $A+C$ \\
\hline $55.0-10-5$ & 0.05 & 26 & 3700 & L. Miocene & $A+C$ \\
\hline $56.2-10-6$ & 0.13 & 150 & 18,750 & U. Oligocene & \\
\hline $58.2-1-6$ & 0.05 & 142 & 9700 & U. Oligocene & $A+C$ \\
\hline \multicolumn{6}{|l|}{ Leg 7} \\
\hline $62.0-3-3$ & $0.9-1.2$ & 502 & 1950 & L. Miocene? & $\mathrm{A}, \mathrm{C}+\mathrm{T}$ \\
\hline $62.1-12-2$ & 0.41 & 86 & 722 & U. Pliocene & $\mathrm{A}, \mathrm{C}+\mathrm{T}$ \\
\hline
\end{tabular}


TABLE 1 - Continued

\begin{tabular}{cccccc}
\hline Sample & $\begin{array}{c}\text { Per Cent } \\
\text { Organic } \\
\text { Carbon }\end{array}$ & $\begin{array}{c}\text { PPM } \\
\text { Heptane } \\
\text { Extract }\end{array}$ & $\begin{array}{c}\text { PPM } \\
\text { Methanol } \\
\text { Extract }\end{array}$ & $\begin{array}{c}\text { Approximate } \\
\text { Age }^{\mathrm{b}}\end{array}$ & $\begin{array}{c}\text { Compound Types } \\
\text { Found }^{\mathrm{c}}\end{array}$ \\
\hline $64.1-2-5$ & 0.24 & 164 & 3060 & M. Miocene & $\mathrm{A}+\mathrm{C}$ \\
$65.0-9-2$ & 0.12 & 210 & $\sim 25,300$ & U. Miocene & $\mathrm{A}, \mathrm{C}+\mathrm{T}$ \\
$65.0-9-6$ & 0.06 & 118 & 2900 & U. Miocene & \\
$65.1-4-3$ & 0.08 & 177 & 7960 & M. Eocene & A, C, S + T \\
$66.0-6-2$ & 0.05 & 259 & 5200 & L. Oligocene & A, C + S \\
$66.0-7-4$ & 0.07 & 18 & 2130 & L. Oligocene & A, C + T \\
\hline
\end{tabular}

${ }^{\mathrm{a}}$ Hole-Core-Section

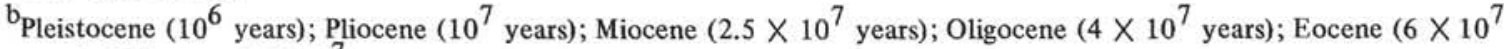
years); Paleocene ( $7 \times 10^{7}$ years).

${ }^{\mathrm{c}}$ Compound Types: A-Alkanes; C-Carboxylic Acids (includes ketones, etc.); S-Steroidal Compounds; T-Triterpenoidal Compounds.

TABLE 2

Various Carbon Skeletons $\left(\mathrm{C}_{\mathrm{n}} \mathrm{H}_{2 \mathrm{n}+(\mathrm{z})}\right)$ Found

\begin{tabular}{|c|c|c|c|}
\hline $\mathrm{Z}$ & $\begin{array}{l}\text { Degrees of } \\
\text { Unsaturation }\end{array}$ & Skeletal Structures of Lowest Homolog & $\begin{array}{l}\text { Found in } \\
\text { the Core } \\
\text { Extracts }\end{array}$ \\
\hline \multirow[t]{5}{*}{+2} & 0 & $\mathrm{C}-\mathrm{C}$ fully saturated & Major \\
\hline & 1 & $\mathrm{C}=\mathrm{C}$ or & Major \\
\hline & 2 & $2 \mathrm{C}=\mathrm{C}$ or & Minor \\
\hline & 3 & $3 \mathrm{C}=\mathrm{C}$ or & Minor \\
\hline & 4 & & Major \\
\hline-8 & 5 & or & Minor \\
\hline-10 & 6 & & Absent \\
\hline-12 & 7 & & Trace \\
\hline
\end{tabular}


conceivably could be derived from the following type of intramolecular oxidative crosslinking of an unsaturated $\mathrm{C}_{18}$ alkane, for example, Structure I.

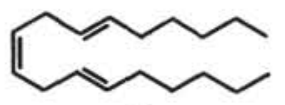

I
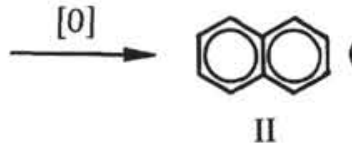

$\left(\mathrm{C}_{4} \mathrm{H}_{9}\right)_{2}$

II

\section{Leg 5, Hole 34-4-4}

This extract contains quite a variety of alkanes, but no significant amounts of oxygenated material. The major series found are $\mathrm{C}_{n} \mathrm{H}_{2 n+2}, \mathrm{C}_{n} \mathrm{H}_{2 n-2}$ and $\mathrm{C}_{n} \mathrm{H}_{2 n-4}$, ranging from $n=10$ to 23. The minor series are $\mathrm{C}_{\mathrm{n}} \mathrm{H}_{2 \mathrm{n}-6}, \mathrm{C}_{\mathrm{n}} \mathrm{H}_{2 \mathrm{n}-8}, \mathrm{C}_{\mathrm{n}} \mathrm{H}_{2 \mathrm{n}-12}$ and $\mathrm{C}_{\mathrm{n}} \mathrm{H}_{2 \mathrm{n}-14}$ for various values of $\mathrm{n}$ from about 9 to a maximum of 23 for some of the series, not every homolog being found.

\section{Leg 5, Hole 32-12-3}

This extract consists mainly of saturated alkanes to about $\mathrm{C}_{13}$ and two compounds of compositions $\mathrm{C}_{16} \mathrm{H}_{32} \mathrm{O}_{2}$ (probably palmitic acid) and $\mathrm{C}_{18} \mathrm{H}_{36} \mathrm{O}_{2}$ (probably stearic acid).

\section{Leg 5, Hole 37-3-0}

The extract is essentially only three hydrocarbon series: $\mathrm{C}_{\mathrm{n}} \mathrm{H}_{2 n}, \mathrm{C}_{\mathrm{n}} \mathrm{H}_{2 n-2}$ and $\mathrm{C}_{\mathrm{n}} \mathrm{H}_{2 \mathrm{n}-6}$, ranging from $\mathrm{n}=10$ to a maximum of 22 . The peak at $\mathrm{m} / \mathrm{e} 217$ of composition $\mathrm{C}_{16} \mathrm{H}_{25}$ (Structure III) is present in the high resolution mass spectral data, lending support to a steroidal structure for the higher members of the

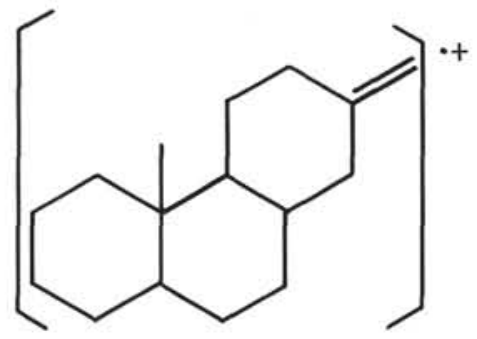

III m/e 217, $\mathrm{C}_{16} \mathrm{H}_{25}$

$\mathrm{C}_{n} \mathrm{H}_{2 n-6}$ series $(n=16-22)$. There is a significant amount of the series $\mathrm{C}_{n} \mathrm{H}_{2 n} \mathrm{O}$ for $\mathrm{n}=10-20$, but only the even members are present. Since alcohols do not exhibit any appreciable molecular ions under $70 \mathrm{eV}$ ionization, this series is postulated to be a series of ethers or ketones.

\section{Leg 5, Hole 34-5-4}

The partial high resolution mass spectral data for this extract is shown in Figure 1 (Burlingame and Smith,
$1968)^{2}$. The general appearance of the data indicates a much more aromatized extract (compare the peaks with tics in the two heteroatomic plots). There were no fatty acids detected above background levels. The steroidal series, $\mathrm{C}_{\mathrm{n}} \mathrm{H}_{2 \mathrm{n}-6}$, is further substantiated by the peak at $\mathrm{m} / \mathrm{e} 217$ of composition $\mathrm{C}_{16} \mathrm{H}_{25}$ (Structure III). The major components however are alkanes of the series: $\mathrm{C}_{n} \mathrm{H}_{2 n+2}$ for $\mathrm{n}=8$ to $18, \mathrm{C}_{n} \mathrm{H}_{2 n}$ for $\mathrm{n}=8$ to 20 , and $\mathrm{C}_{\mathrm{n}} \mathrm{H}_{2 \mathrm{n}-2}$ for $\mathrm{n}=8$ to 21 .

\section{Leg 5, Hole 34-10-1}

The partial high resolution mass spectral data of this heptane extract is shown in Figure 2 and exhibits mainly molecular ions of four degrees of unsaturation. The fragment peaks of compositions $\mathrm{C}_{16} \mathrm{H}_{25}$ (Structure III) at $\mathrm{m} / \mathrm{e} 217, \mathrm{C}_{14} \mathrm{H}_{23}$ (Structure IV) at $\mathrm{m} / \mathrm{e} 191$ and $\mathrm{C}_{13} \mathrm{H}_{21}$ (Structure V) at $\mathrm{m} / \mathrm{e} 177$ are all present above background, indicating possible steroidal and pentacyclic triterpenoidal structures for the $\mathrm{C}_{n} \mathrm{H}_{2 n-6}$ and $\mathrm{C}_{n} \mathrm{H}_{2 n-8}$ series ( $\mathrm{n}$ found: 34,36 and 40 ), as well as the $\mathrm{C}_{n} \mathrm{H}_{2 n-6} \mathrm{O}$ and $\mathrm{C}_{n} \mathrm{H}_{2 n-8} \mathrm{O}$ series (n found: $22,24,25,32$ and 38 ) are present. The $\mathrm{C}_{40}$ alkane (see to compare peak $\mathrm{C}_{40} \mathrm{H}_{74}$ in the $\mathrm{C} / \mathrm{H}$ plot<smiles>[CH2+]C1=CC2(C)CCCC(C)(C)C2CC1</smiles>

IV m/e 191, $\mathrm{C}_{14} \mathrm{H}_{23}$<smiles>[CH2+]C1=CC2(C)CCCC(C)C2CC1</smiles>

V m/e 177, $\mathrm{C}_{13} \mathrm{H}_{21}$ of Figure 2) fits a carotenoidal structure, such as VI. The series $\mathrm{C}_{n} \mathrm{H}_{2 n-4}$ and $\mathrm{C}_{n} \mathrm{H}_{2 n-2}$ are found in minor

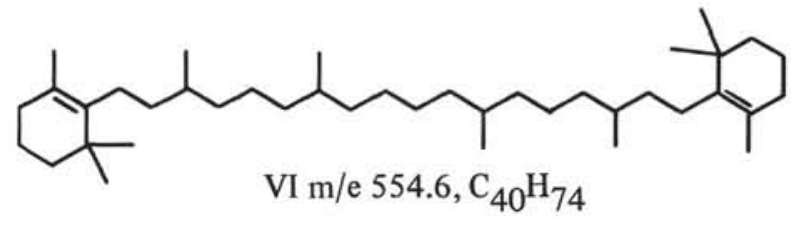

\footnotetext{
${ }^{2}$ The high resolution mass spectra are presented as heteroatomic plots. The masses are plotted in methylene units. On the abscissa, each principal division marker corresponds to the saturated alkyl fragment, for example, $\mathrm{C}_{n} \mathrm{H}_{2 n+1}$, with the number of carbon/hydrogen atoms given below. There are fourteen units between each principal division, and the number of hydrogen atoms of an unsaturated or cyclic fragment ion is obtained simply by subtracting the number of units (hydrogens) from the $2 n+1$ hydrogens of the respective saturated principal division, $\mathrm{C}_{n} \mathrm{H}_{2 n+1}$. A peak with a single tic mark above it indicates more than seven degrees of unsaturation. Fragments of this kind are plotted below the next lower major saturated division, that is, $\mathrm{C}_{\mathrm{n}-1} \mathrm{H}_{2 \mathrm{n}-1}$. To convert the apparent composition of these ions as they appear on the plot to their actual composition, add one carbon and subtract 12 hydrogen atoms. A peak with a double tic mark above it indicates more than 14 degrees of unsaturation. Fragments of this kind are plotted below the next two lower major saturated divisions, that is, $\mathrm{C}_{\mathrm{n}-2} \mathrm{H}_{2 \mathrm{n}-3}$, and are converted to their actual composition by adding two carbons and subtracting 24 hydrogen atoms.
} 

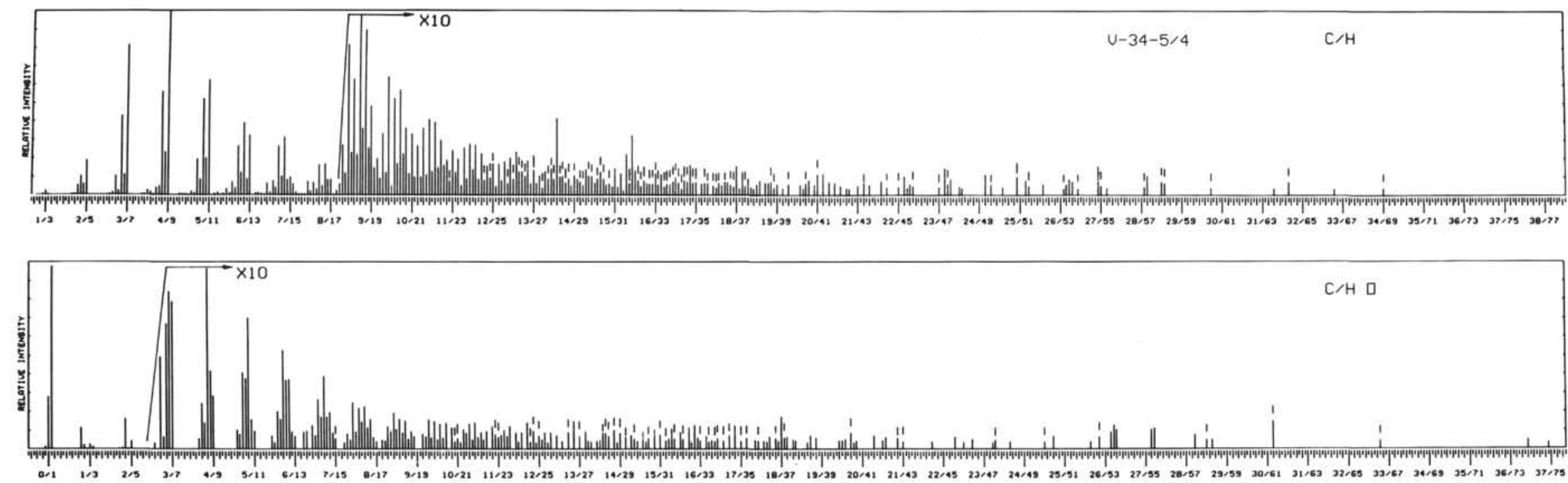

Figure 1. Partial summed high resolution mass spectral data for the total extract from Leg 5, Core 34-5-4. 

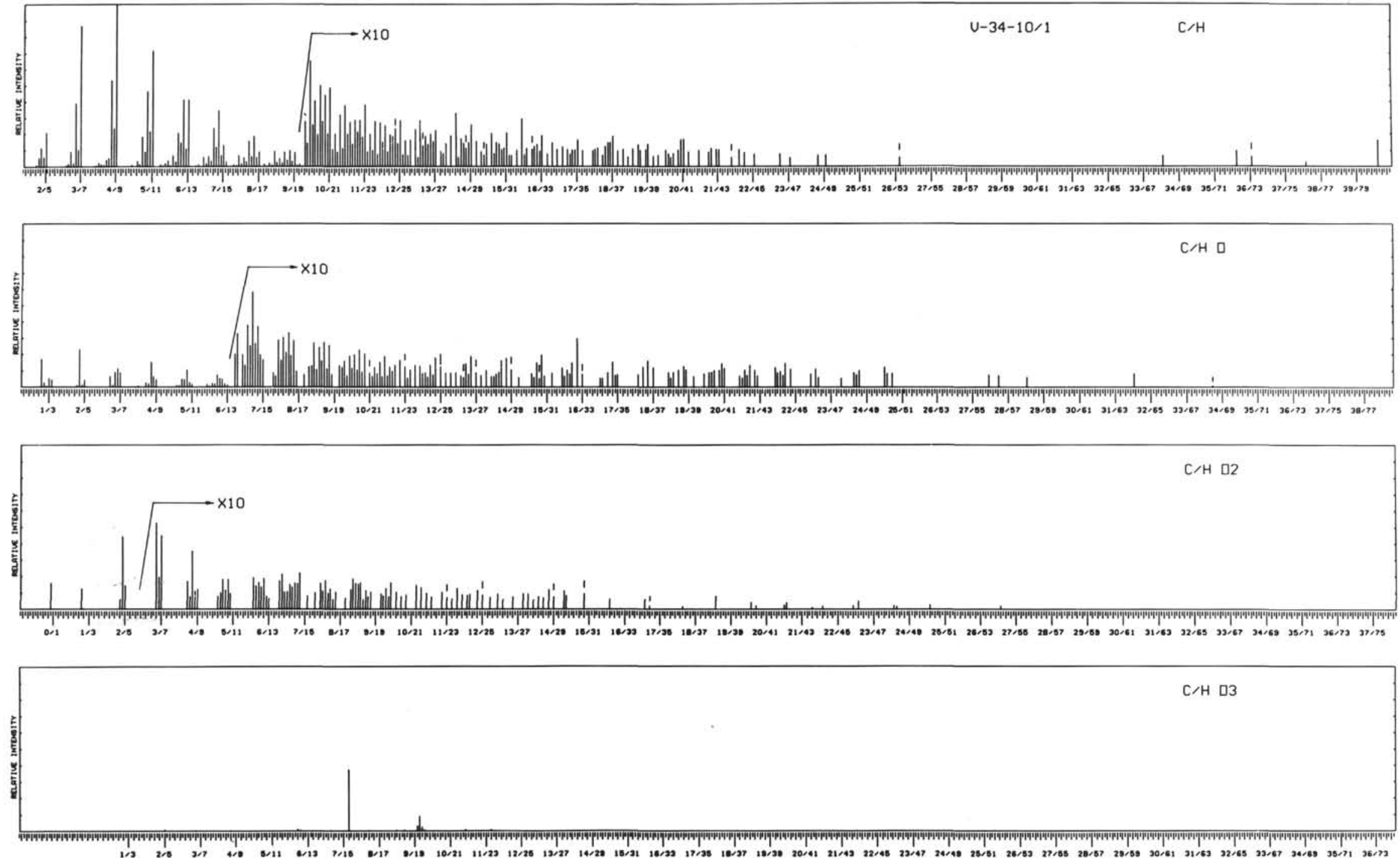

Figure 2. Partial summed high resolution mass spectral data for the total heptane extract from Leg 5, Core 34-10-1. 
amounts, the high molecular weight members being $\mathrm{n}=18,20,21,22$ and 24 , but ranging down to $\mathrm{n}=10$. The saturated series $\mathrm{C}_{n} \mathrm{H}_{2 n+2}, \mathrm{C}_{n} \mathrm{H}_{2 n}$ and $\mathrm{C}_{n} \mathrm{H}_{2 n-2}$ are deduced present from the respective fragments for $\mathrm{n} \cong 10$ to 20 . The monooxygenated species consist of $\mathrm{C}_{\mathrm{n}} \mathrm{H}_{2 \mathrm{n}} \mathrm{O}$ for $\mathrm{n}=1$ to 20 and two peaks of composition $\mathrm{C}_{38} \mathrm{H}_{58} \mathrm{O}$ and $\mathrm{C}_{29} \mathrm{H}_{52} \mathrm{O}$. Small amounts of dioxygenated species are also present: $\mathrm{C}_{21} \mathrm{H}_{36} \mathrm{O}_{2}$ and $\mathrm{C}_{24} \mathrm{H}_{44} \mathrm{O}_{2}$ and the fragment ion series $\mathrm{C}_{\mathrm{n}} \mathrm{H}_{2 \mathrm{n}-5} \mathrm{O}_{2}$ for $n=5$ to 14,16 to 25 and 27 . The large peak of composition $\mathrm{C}_{8} \mathrm{H}_{5} \mathrm{O}_{3}$ in the $\mathrm{C} / \mathrm{H} \mathrm{O}_{3}$ plot of Figure 2 is derived from phthalate ester contamination and is assigned Structure VII. The source of this type of

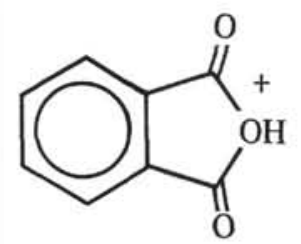

VII m/e $149, \mathrm{C}_{8} \mathrm{H}_{5} \mathrm{O}_{3}$

contamination is discussed later in this report. The group of peaks at $\mathrm{C}_{10} \mathrm{H}_{9} \mathrm{O}_{3}$ in the same plot are also phthalate ester fragments; such as, possibly Structure VIII.

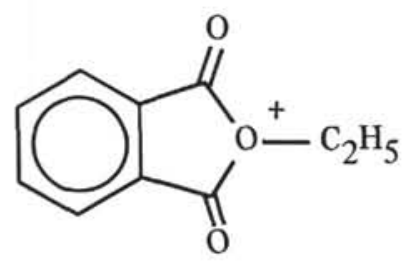

VII m/e $177, \mathrm{C}_{10} \mathrm{H}_{9} \mathrm{O}_{3}$

\section{Leg 7, Hole 62.0-3-3}

The partial high resolution mass spectral data is found in Figure 3. The virtual absence of low weight fragments should be noted. The higher weight species are $\mathrm{C}_{40} \mathrm{H}_{54}$ and $\mathrm{C}_{32} \mathrm{H}_{58}$ in the $\mathrm{C} / \mathrm{H}$ plot of Figure 3. Also the peak of composition $\mathrm{C}_{18} \mathrm{H}_{12}$ in the same plot can be considered as chrysene (Structure IX) or tetracene.

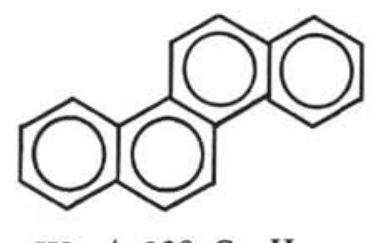

$$
\text { IX m/e 228, } \mathrm{C}_{18} \mathrm{H}_{12}
$$

The peaks of composition $\mathrm{C}_{38} \mathrm{H}_{39} \mathrm{O}, \mathrm{C}_{36} \mathrm{H}_{49} \mathrm{O}$ and $\mathrm{C}_{33} \mathrm{H}_{66} \mathrm{O}$ are the only species found at high mass in the $\mathrm{C} / \mathrm{H} \mathrm{O}$ plot.

\section{Leg 7, Hole 62.1-12-2}

The partial high resolution mass spectral data for this extract is shown in Figure 4. Again, the major constituents are the alkane series: $\mathrm{C}_{n} \mathrm{H}_{2 n+2}$ (deduced mostly from its fragments), $\mathrm{C}_{\mathrm{n}} \mathrm{H}_{2 n}, \mathrm{C}_{\mathrm{n}} \mathrm{H}_{2 \mathrm{n}-2}$ and $\mathrm{C}_{\mathrm{n}} \mathrm{H}_{2 \mathrm{n}-4}$ for $\mathrm{n} \cong 8$ to 22 . The group of peaks at high mass in the $\mathrm{C} / \mathrm{H}$ plot of Figure 4 are of the series $\mathrm{C}_{\mathrm{n}} \mathrm{H}_{2 \mathrm{n}-6}$ for $\mathrm{n}=34,36,38$ and 40 (even carbon numbers only). This series could be of carotenoidal structure (for example, Structure VI). The peaks at $\mathrm{m} / \mathrm{e} 217$, $\mathrm{C}_{16} \mathrm{H}_{25}$ and $\mathrm{m} / \mathrm{e} 191, \mathrm{C}_{14} \mathrm{H}_{23}$ are slightly above the background and indicate minor amounts of steroidal and triterpenoidal compounds. The fatty acids are minor constituents, the peak of composition $\mathrm{C}_{16} \mathrm{H}_{32} \mathrm{O}_{2}$ (probably palmitic acid) being the most intense molecular ion found in the series. The large peak in the $\mathrm{C} / \mathrm{H} \mathrm{O}_{3}$ plot of Figure 4 has the composition $\mathrm{C}_{8} \mathrm{H}_{5} \mathrm{O}_{3}$ (Structure VII) and is sample contamination as discussed later. It is derived in this case from dioctyl phthalate (the most ubiquitous member of the phthalate esters), as substantiated by the two peaks found of composition $\mathrm{C}_{8} \mathrm{H}_{7} \mathrm{O}_{4}$ at m/e 167 (Structure $\mathrm{X}$ ) and $\mathrm{C}_{16} \mathrm{H}_{23} \mathrm{O}_{4}$ at $\mathrm{m} / \mathrm{e} 279$ (Structure XI). Dioctyl phthalate exhibits no molecular ion.<smiles>C=C(O)c1ccccc1C(=O)O</smiles>

$$
\mathrm{X} \mathrm{m} / \mathrm{e} 167, \mathrm{C}_{8} \mathrm{H}_{7} \mathrm{O}_{4}
$$<smiles></smiles>

$\mathrm{XI} \mathrm{m} / \mathrm{e} 279, \mathrm{C}_{16} \mathrm{H}_{23} \mathrm{O}_{4}$

\section{Leg 7, Hole 65.0-9-2}

The partial high resolution mass spectra data for this heptane extract is shown in Figure 5. The $\mathrm{C}_{40} \mathrm{H}_{74}$ peak (Structure VI) is present and the following series is found in major amounts at high mass in the $\mathrm{C} / \mathrm{H}$ 

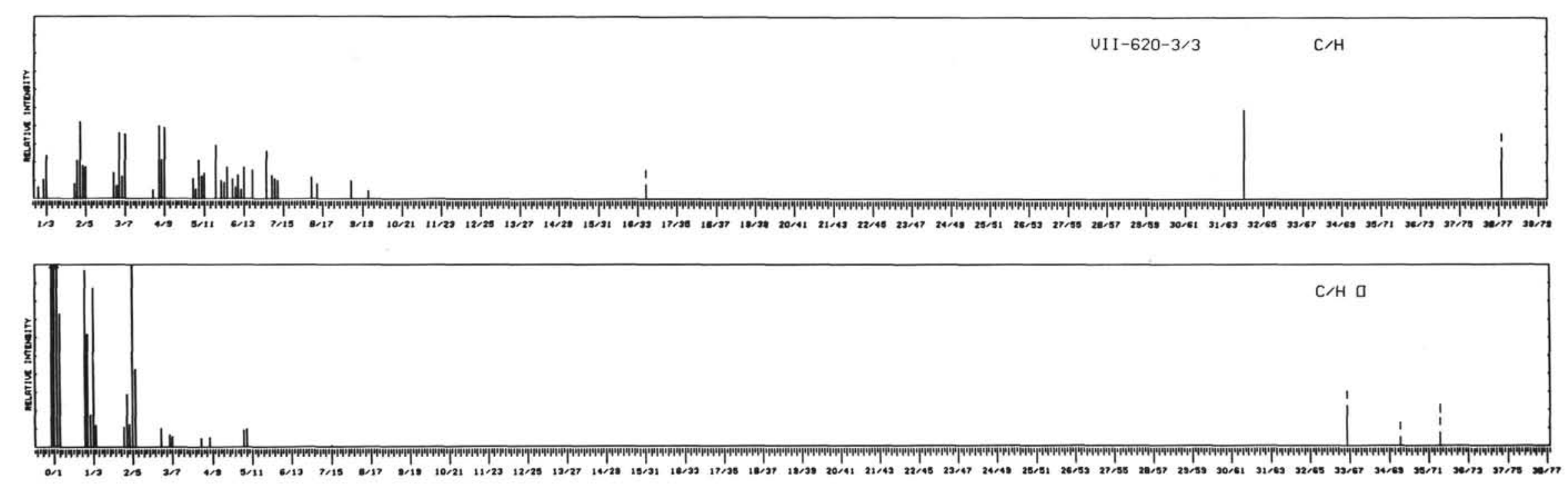

Figure 3. Partial summed high resolution mass spectral data for the extract from Leg 7, Core 62.0-3-3. 

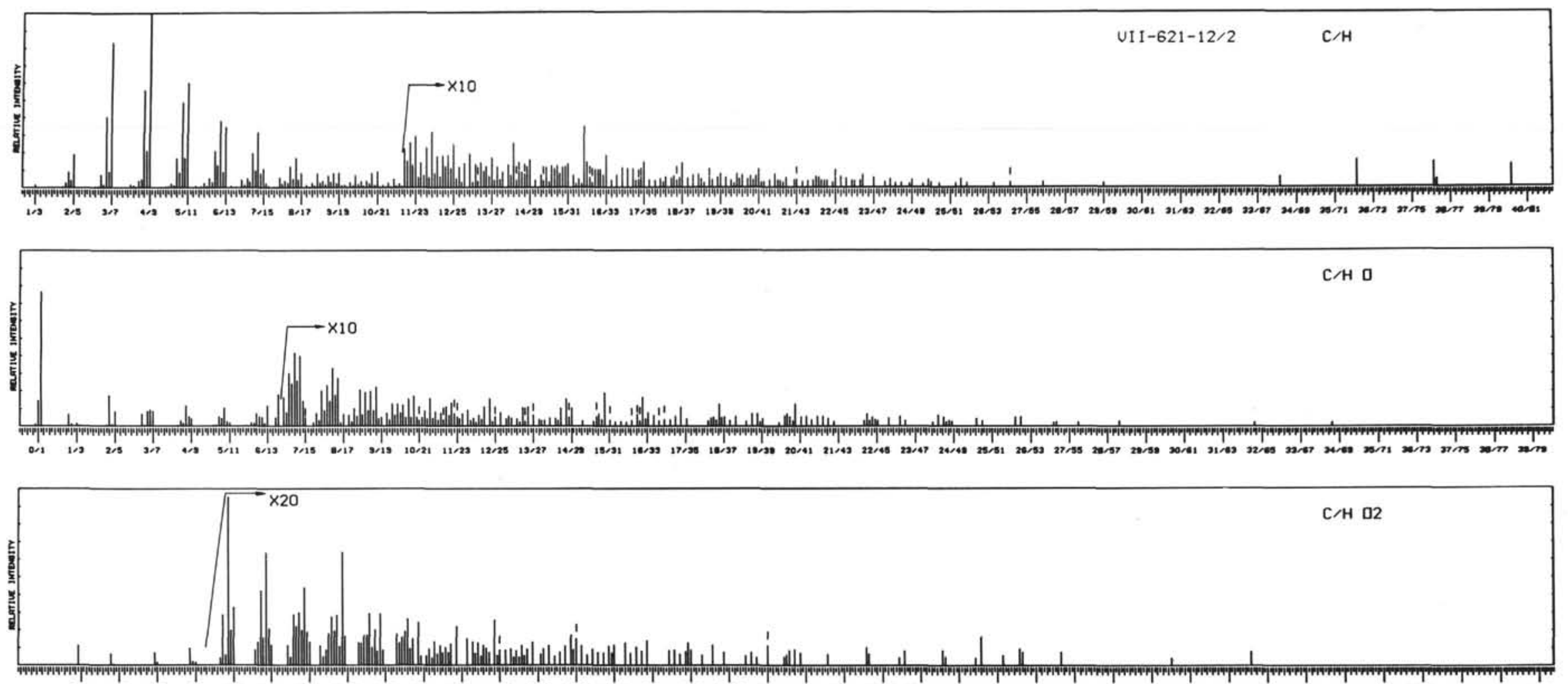

C/H $03 \times 10$

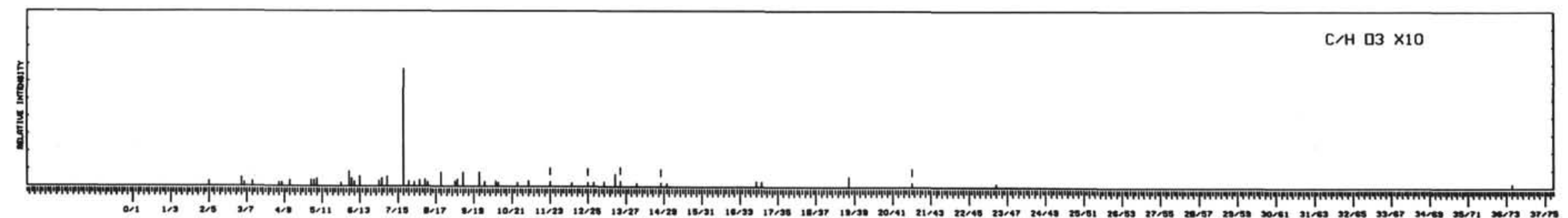

Figure 4. Partial summed high resolution mass spectral data for the extract from Leg 7, Core 62.1-12-2. 

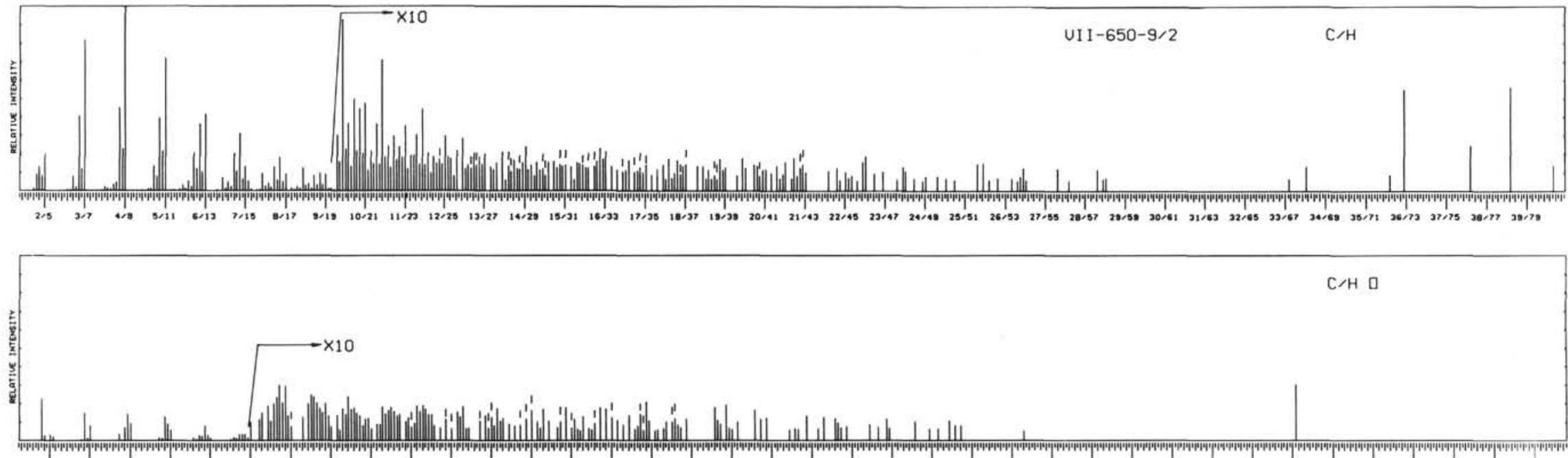

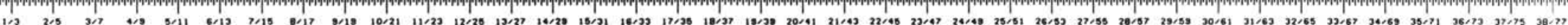

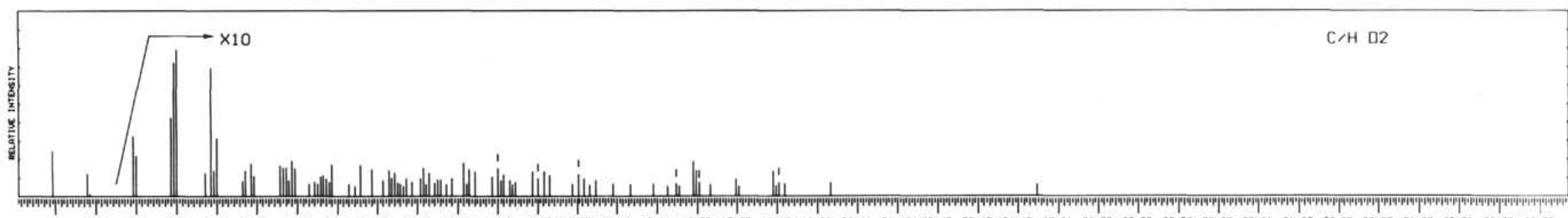

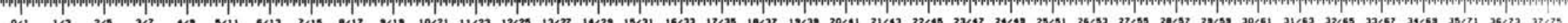

Figure 5. Partial summed high resolution mass spectral data for the heptane extract from Leg 7, Core 65.0-9-2. 
plot: $\mathrm{C}_{n} \mathrm{H}_{2 \mathrm{n}-6}$ for $\mathrm{n}=29,34,36,38$ and 40 . The series $\mathrm{C}_{\mathrm{n}} \mathrm{H}_{2 \mathrm{n}}$ occurs in minor amounts for $\mathrm{n}=18$ and 20 . The other hydrocarbon series are present in minor amounts, as substantiated by the respective fragment ion peaks. There are also ions fitting polycyclic structures with 26 to 29 carbon atoms. The major fatty acid found is $\mathrm{C}_{18} \mathrm{H}_{36} \mathrm{O}_{2}$ (probably stearic acid) and less of $\mathrm{C}_{17} \mathrm{H}_{34} \mathrm{O}_{2}$. The series is indicated by the presence of the fragment ions of composition $\mathrm{C}_{\mathrm{n}} \mathrm{H}_{2 \mathrm{n}-1} \mathrm{O}_{2}$ for $\mathrm{n}=6$ to 16 .

\section{Leg 7, Hole 65.1-43}

The partial high resolution mass spectral data appears in Figure 6. This extract contains mostly low molecular weight alkanes, such as the series fragments $\mathrm{C}_{n} \mathrm{H}_{2 n+1}$ for $n=2$ to 23 and $\mathrm{C}_{n} \mathrm{H}_{2 n-1}$ for $\mathrm{n}=2$ to 16 and 18 . The series $\mathrm{C}_{n} \mathrm{H}_{2 n-6}$ is indicated present for $\mathrm{n}=36,38$ and 40 . The $\mathrm{C} / \mathrm{HO}$ plot consists mainly of ions of composition $\mathrm{C}_{\mathrm{n}} \mathrm{H}_{2 \mathrm{n}-1} \mathrm{O}$ for $\mathrm{n}=1$ to 12,14 to 20 and $\mathrm{C}_{\mathrm{n}} \mathrm{H}_{2 \mathrm{n}} \mathrm{O}$ for $\mathrm{n}=16$ and 20. The molecular ions of composition $\mathrm{C}_{16} \mathrm{H}_{32} \mathrm{O}_{2}$ (possibly palmitic acid) and $\mathrm{C}_{15} \mathrm{H}_{30} \mathrm{O}_{2}$ are found in the $\mathrm{C} / \mathrm{H} \mathrm{O}_{2}$ plot; the lower homologs are indicated present in minor amounts by their respective fragment ions $\mathrm{C}_{n} \mathrm{H}_{2 n-1} \mathrm{O}_{2}$ for $\mathrm{n} \cong 1$ to 14. At high mass there is a peak of composition $\mathrm{C}_{37} \mathrm{H}_{74} \mathrm{O}_{2}$ which possibly could be a wax ester. For comparison purposes with the high resolution mass spectral data, a scan at low resolution is shown in Figure 7. The overall appearance of the spectrum fits for alkanes but the peaks at higher mass should be noted. The peak at $\mathrm{m} / \mathrm{e} 256$ corresponds to the composition $\mathrm{C}_{16} \mathrm{H}_{32} \mathrm{O}_{2}$ and the molecular ions at $\mathrm{m} / \mathrm{e} 498,526$ and 554 correspond to the compositions $\mathrm{C}_{\mathrm{n}} \mathrm{H}_{2 \mathrm{n}-6}$ for $\mathrm{n}=36,38$ and 40 , the carotenoidal (Structure VI) type alkanes.

\section{LARGER SAMPLE ANALYSES}

The larger samples packed and frozen in Kapak pouches were defrosted and extracted under a nitrogen atmosphere with $3: 1$ benzene/methanol in a Soxhlet extractor. The procedures used for extraction and functional group separations were the same as described by Burlingame et al. (1969), except that all operations were carried out under nitrogen wherever possible and the isolated fractions were stored under refrigeration.

\section{Leg 5, Hole 35-6-3}

The benzene/methanol (3:1) extract of 68.3 grams of this core was extracted with methylene chloride $\left(\mathrm{CH}_{2} \mathrm{Cl}_{2}\right)$ yielding 16.1 milligrams residue after solvent removal equivalent to $236 \mathrm{ppm}$. This fraction was separated by the wet chemical methods described by Burlingame et al. (1969) into acids, 15.6 per cent of the extract; alkanes (neutrals), 68.0 per cent of the extract; and bases, less than 1 per cent of the extract. A gas chromatogram of the total $\mathrm{CH}_{2} \mathrm{Cl}_{2}$ extract is shown in Figure 8 , and a gas chromatogram of the alkane fraction in Figure 9. The acids were esterified with $\mathrm{BF}_{3}$ in methanol, and the gas chromatogram is shown in Figure 10. A low resolution mass spectrum of the total extract was run and is shown in Figure 11. The major peaks at high mass are at $\mathrm{m} / \mathrm{e} 858$, then a series at $\mathrm{m} / \mathrm{e} 502,516,530,542$ and 544 and groups

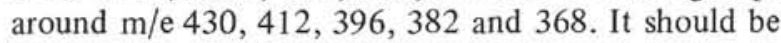
noted that the peak at m/e 191 (probably Structure IV) is significantly above the background. The partial high resolution mass spectral data for the same extract is shown in Figure 12. The major constituents indicated are the alkane series $\mathrm{C}_{n} \mathrm{H}_{2 n+2}, \mathrm{C}_{n} \mathrm{H}_{2 n}$, and $\mathrm{C}_{\mathrm{n}} \mathrm{H}_{2 \mathrm{n}-2}$ to $\mathrm{C}_{\mathrm{n}} \mathrm{H}_{2 \mathrm{n}-12}$ for most values of $\mathrm{n}=2$ to 20 , with the more saturated series being the more abundant. The aromatic series plotted in the aromatic $\mathrm{C} / \mathrm{H}$ plot of Figure 12 are only trace constituents. ${ }^{3}$ At higher mass the series $\mathrm{C}_{n} \mathrm{H}_{2 n-8}$ for $\mathrm{n}=27$ and 29, $\mathrm{C}_{\mathrm{n}} \mathrm{H}_{2 \mathrm{n}-10}$ for $\mathrm{n}=28$ and 29 and $\mathrm{C}_{\mathrm{n}} \mathrm{H}_{2 \mathrm{n}-12}$ for $\mathrm{n}=27$, 28 and 29 , as well as, several fragments appear quite strongly. This series appears to be a group of pentacyclic triterpenoidal molecules, as further substantiated by the peak of composition $\mathrm{C}_{14} \mathrm{H}_{23}$ (Structure IV, $\mathrm{m} / \mathrm{e} \mathrm{191)}$, which is diagnostic for such structures. The $\mathrm{C} / \mathrm{H} \mathrm{O}$ plot of Figure 12 exhibits mainly low weight fragment peaks and the high weight series $\mathrm{C}_{n} \mathrm{H}_{2 n-10} \mathrm{O}$ for $\mathrm{n}=27,29$ and $30, \mathrm{C}_{\mathrm{n}} \mathrm{H}_{2 \mathrm{n}-12} \mathrm{O}$ for $\mathrm{n}=27$ to 30 and $\mathrm{C}_{n} \mathrm{H}_{2 n-8} \mathrm{O}$ for $\mathrm{n}=28$. The ions of interest in the $\mathrm{C} / \mathrm{H} \mathrm{O}_{2}$ plot of Figure 12 are the series $\mathrm{C}_{\mathrm{n}} \mathrm{H}_{2 \mathrm{n}} \mathrm{O}_{2}$ for $\mathrm{n}=2$ to 7,16 to $18,21,22,25,26,28$ and 30 .

The alkanes (neutrals) were analyzed by high resolution mass spectrometry and the data indicated mainly hydrocarbons with minor amounts of oxygenated species. The saturated series $\mathrm{C}_{n} \mathrm{H}_{2 n+2}, \mathrm{C}_{n} \mathrm{H}_{2 n}$ and $\mathrm{C}_{n} \mathrm{H}_{2 n-2}$ for $\mathrm{n}=1$ to 18 are the major constituents. At high mass are significant peaks of compositions $\mathrm{C}_{16} \mathrm{H}_{26}, \mathrm{C}_{27} \mathrm{H}_{46}, \mathrm{C}_{29} \mathrm{H}_{48}$ and a strong $\mathrm{C}_{31} \mathrm{H}_{56}$ fitting molecular ions, and the fragments $\mathrm{C}_{19} \mathrm{H}_{27}$, $\mathrm{C}_{30} \mathrm{H}_{39}$ and $\mathrm{C}_{37} \mathrm{H}_{57}$. The major $\mathrm{C} / \mathrm{H} \mathrm{O}$ peaks at high mass are a group around $\mathrm{m} / \mathrm{e} 502$ of compositions such as $\mathrm{C}_{36} \mathrm{H}_{56} \mathrm{O}$.

The methyl esters were also subjected to high resolution mass spectrometry and the data are shown in Figure 13. The salient features of this data are as follows. The saturated acid esters of the series $\mathrm{C}_{\mathrm{n}} \mathrm{H}_{2 \mathrm{n}} \mathrm{O}_{2}$ for $\mathrm{n}=1$ to 21 (the lowest homologs being mostly rearrangement ions), $\mathrm{C}_{\mathrm{n}} \mathrm{H}_{2 \mathrm{n}-2} \mathrm{O}_{2}$ for $\mathrm{n}=1$ to 20 and $\mathrm{C}_{n} \mathrm{H}_{2 n-4} \mathrm{O}_{2}$ for $\mathrm{n}=1$ to 19 are present,

\footnotetext{
${ }^{3}$ Aromatics usually exhibit only strong molecular ions or $\mathrm{M}-\mathrm{HC}=\mathrm{CH}$ type fragments, also of high relative intensity. Thus, abundance quantitation of these series is only an estimate and probably on the high side.
} 

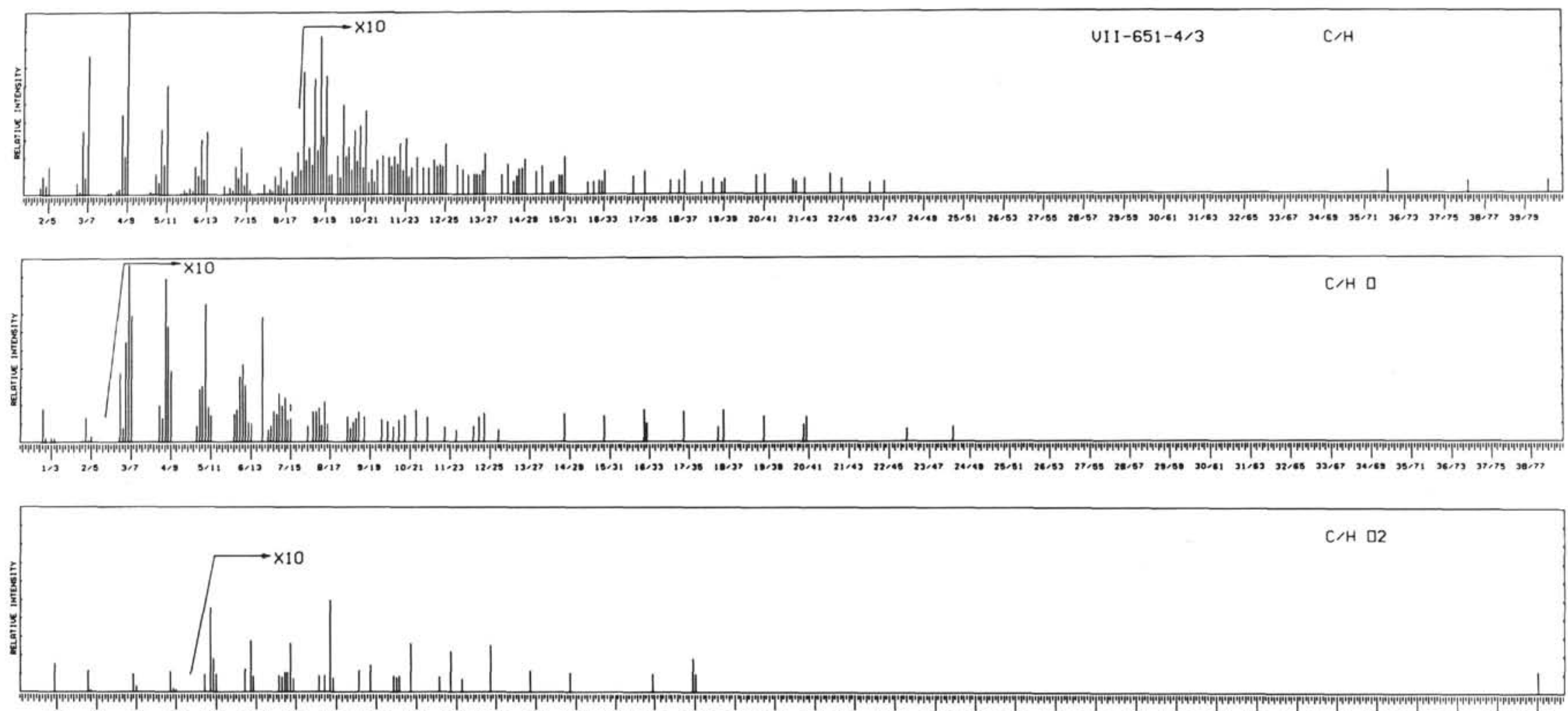



Figure 6. Partial summed high resolution mass spectral data for the extract from Leg 7, Core 65.1-4-3.

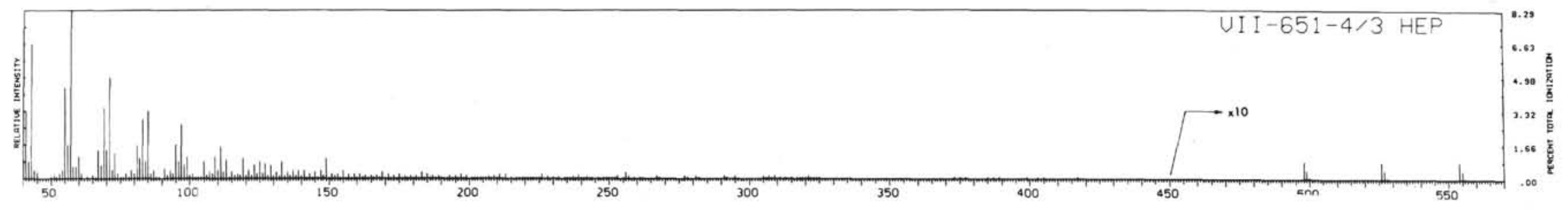

Figure 7. Low resolution mass spectrum of the extract from Leg 7, Core 65.1-4-3. 


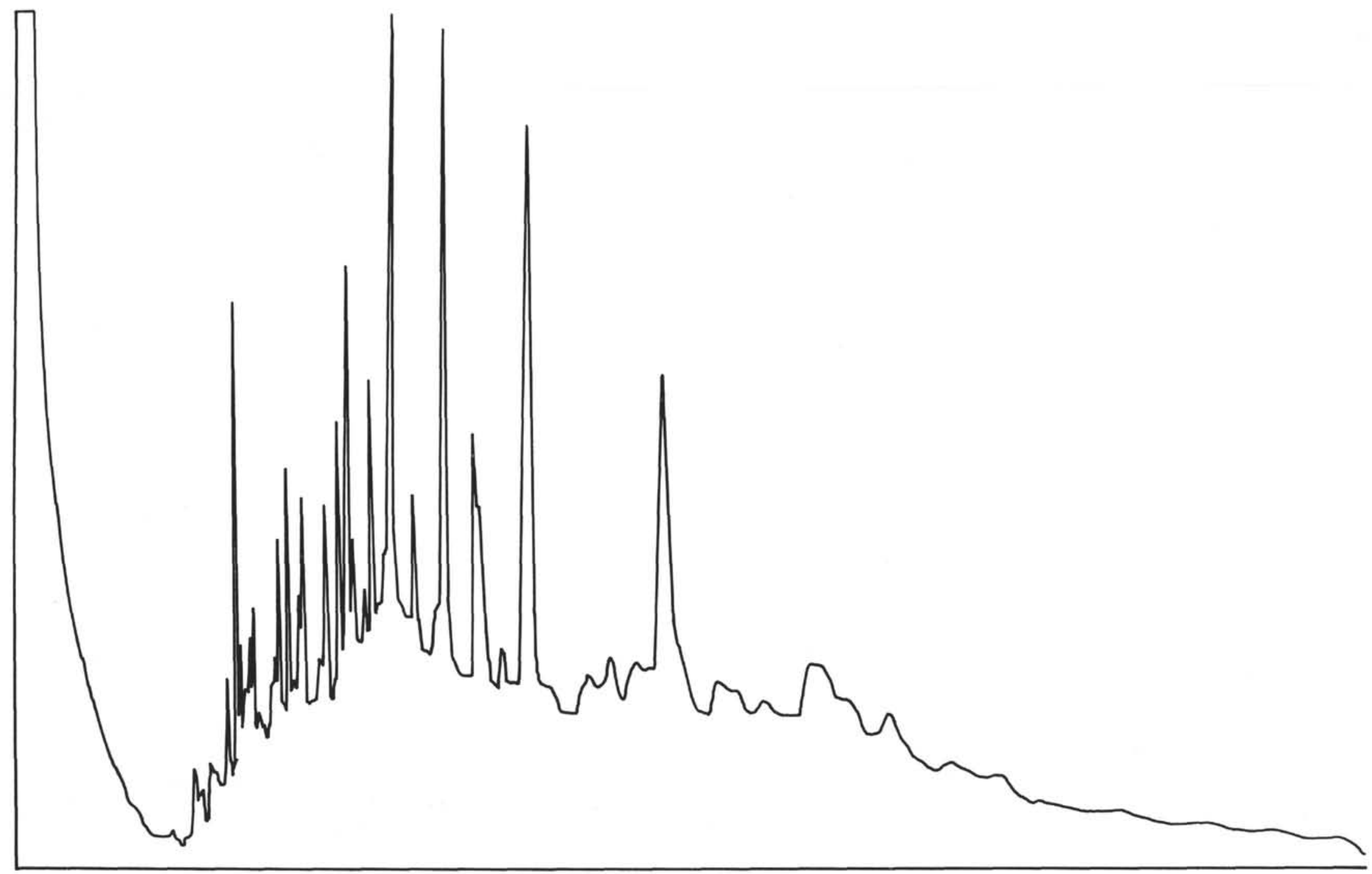

Figure 8. Gas chromatogram of the total methylene chloride extract from Leg 5, Core 35-6-3 (conditions: $10 \mathrm{ft}$. x $1 / 8$ " stainless steel column, packed with 3 per cent SE-30 on 100-120 mesh Gaschrom Q, programmed from 100-250 ${ }^{\circ} \mathrm{C}$ at $8^{\circ} /$ minute and using helium at $40 \mathrm{ml} / \mathrm{minute}$ ). 


$$
\text { 此 }
$$




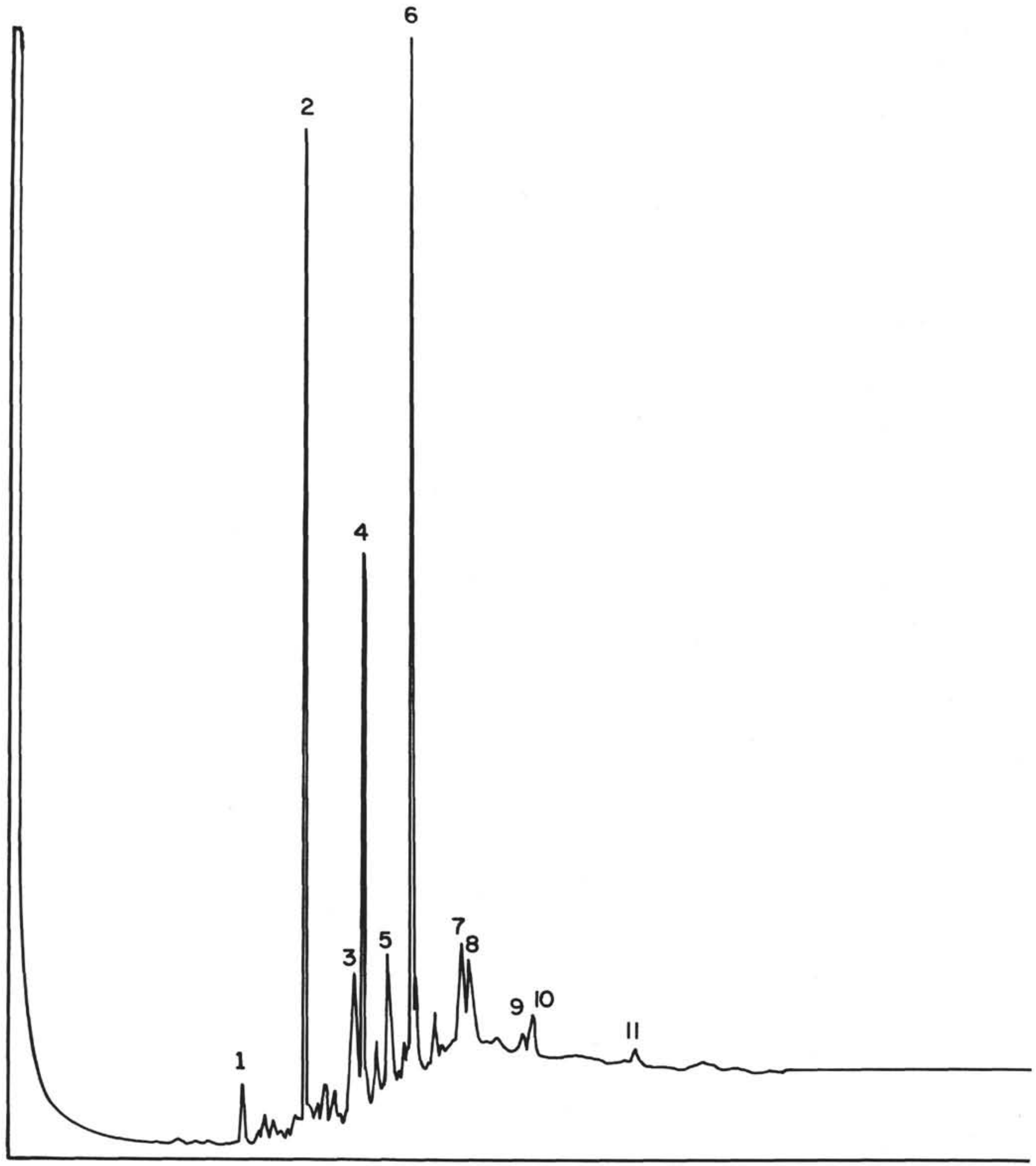

Figure 10. Gas chromatogram of the acid methyl esters from the methylene chloride extract of Leg 5, Core 35-6-3 (conditions as cited in Figure 8). 


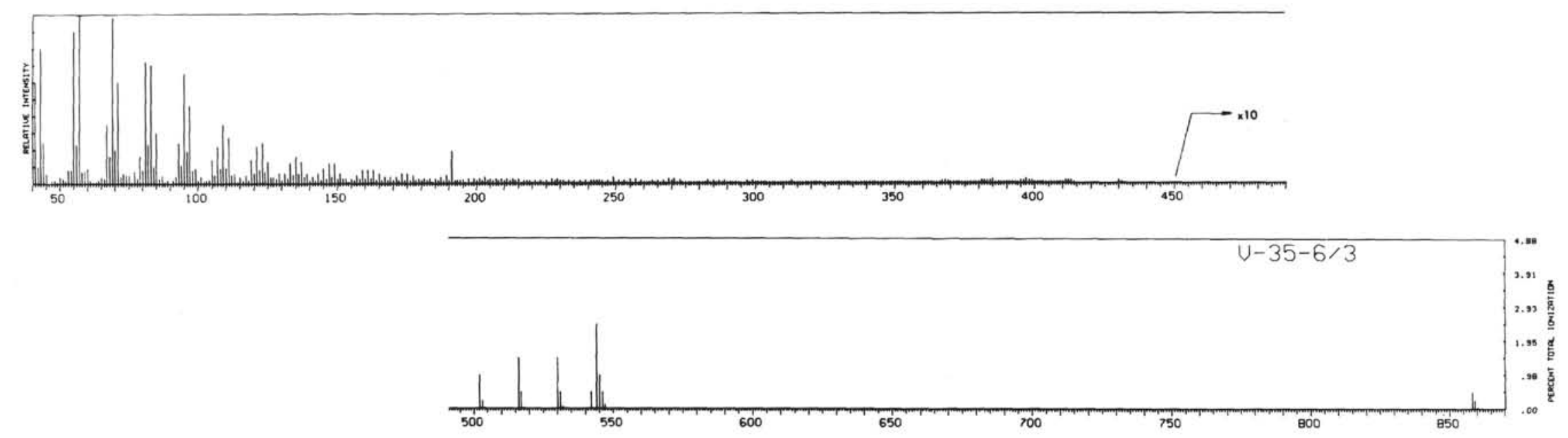

Figure 11. Low resolution mass spectrum of the total methylene chloride extract from Leg 5, Core 35-6-3. 

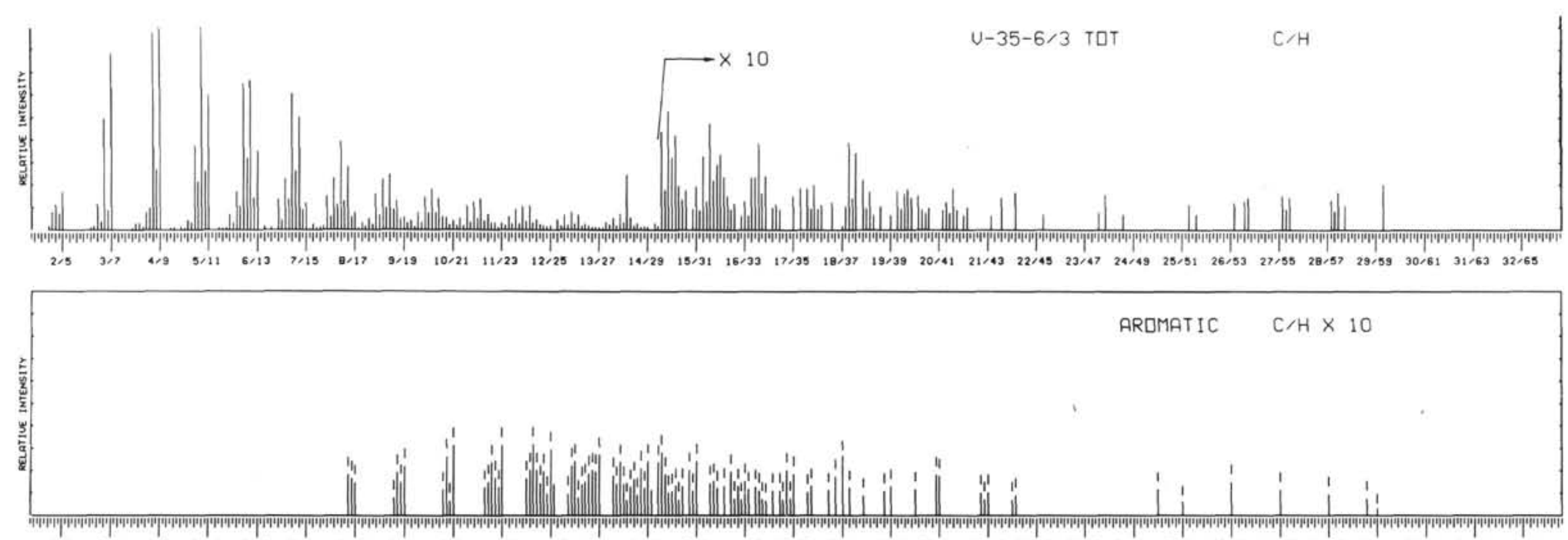

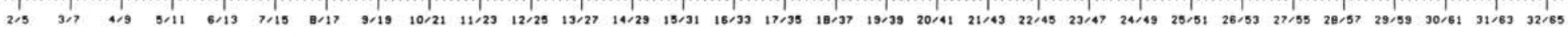

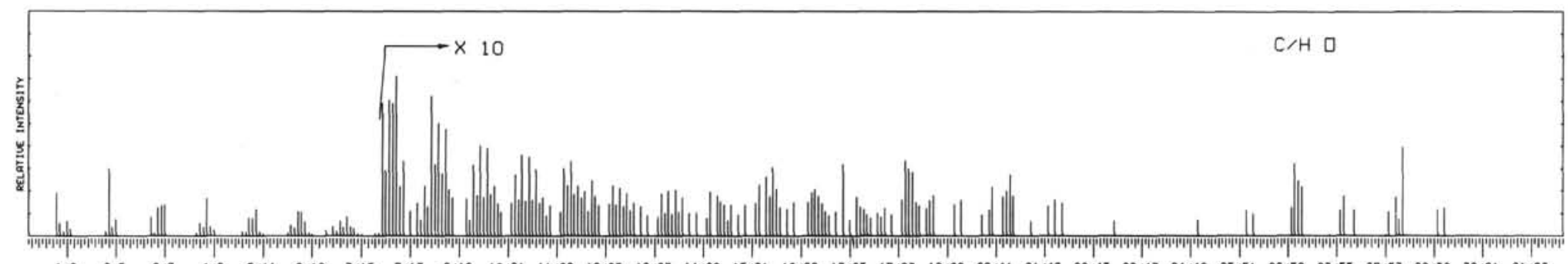

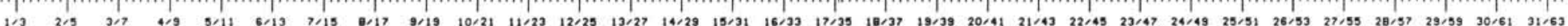

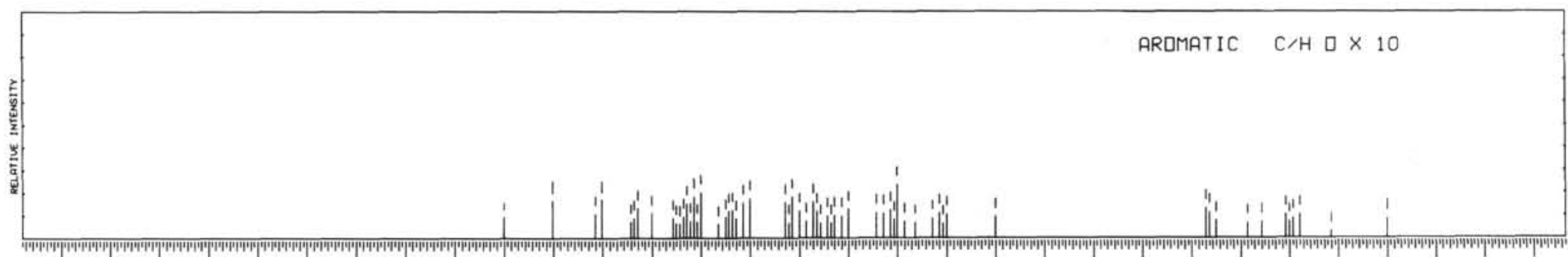

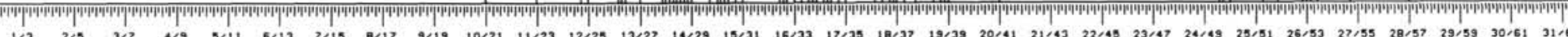

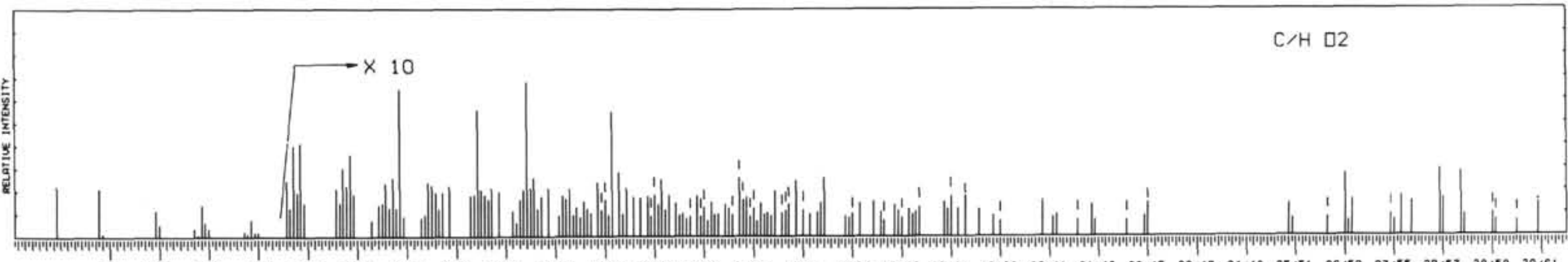

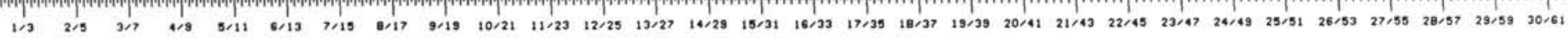

Figure 12. Partial summed high resolution mass spectral data for the total methylene chloride extract from Leg 5, Core 35-6-3. 
ฉু

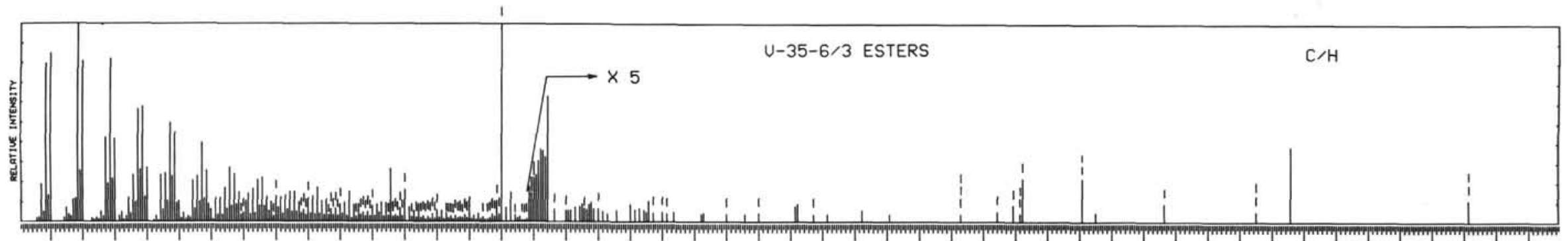

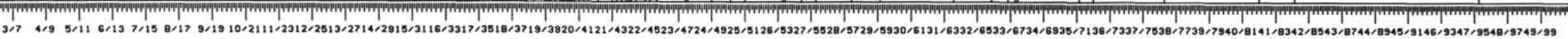

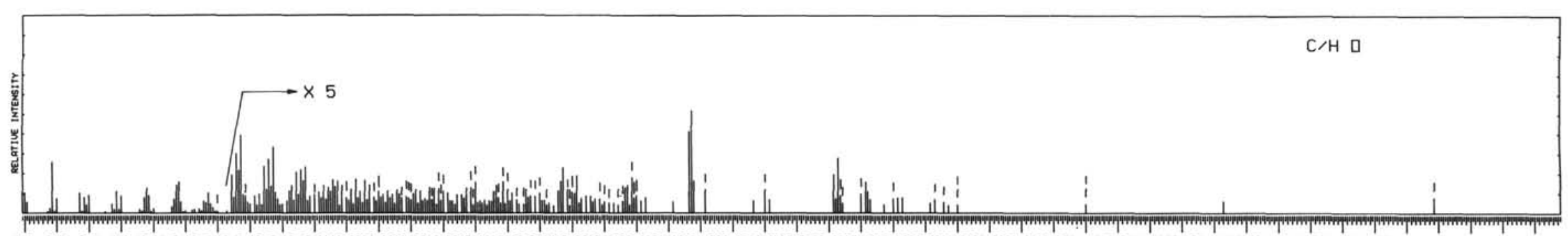

1/3

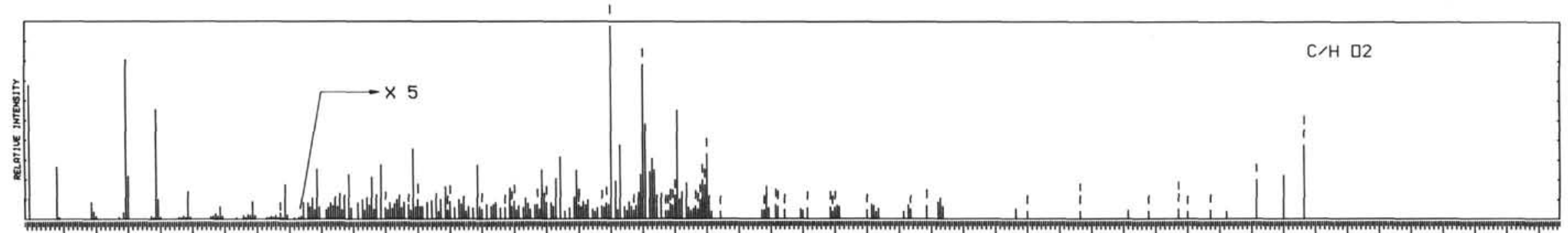

等

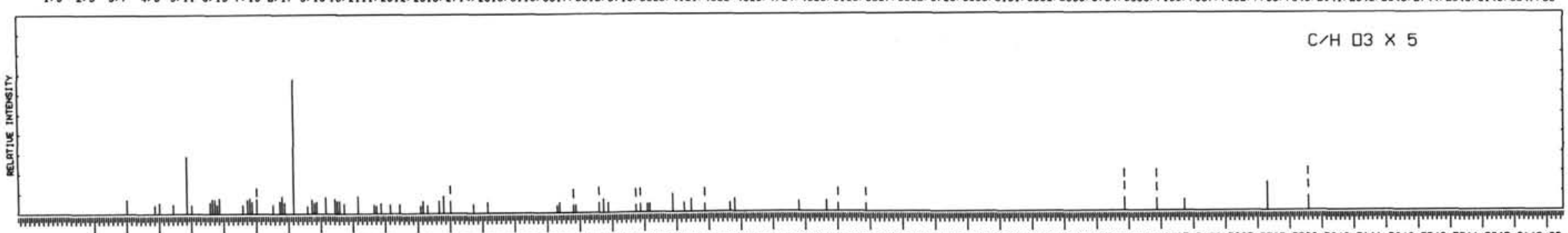

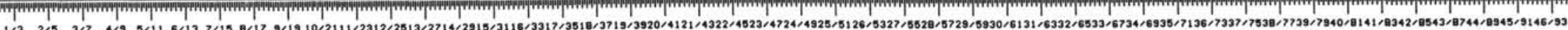

Figure 13. Partial summed high resolution mass spectral data for the methyl esters derived from Leg 5, Core 35-6-3. 
although in low concentrations. At higher mass in the $\mathrm{C} / \mathrm{H} \mathrm{O}_{2}$ plot of Figure 13 are strong ions of compositions $\mathrm{C}_{19} \mathrm{H}_{25} \mathrm{O}_{2}$ and $\mathrm{C}_{20} \mathrm{H}_{27} \mathrm{O}_{2}$ and molecular ions of the series $\mathrm{C}_{\mathrm{n}} \mathrm{H}_{2 \mathrm{n}-12} \mathrm{O}_{2}$ for $\mathrm{n}=20,21,22$ and 26 and various unsaturated or cyclic species with 23 to 29 carbons. The peak at composition $\mathrm{C}_{39} \mathrm{H}_{78} \mathrm{O}_{2}$ fits into the $\mathrm{C}_{\mathrm{n}} \mathrm{H}_{2 \mathrm{n}} \mathrm{O}_{2}$ series and could be a wax ester. The large peak on the $\mathrm{C} / \mathrm{H} \mathrm{O}_{3}$ plot of composition $\mathrm{C}_{8} \mathrm{H}_{5} \mathrm{O}_{3}$ (Structure VII) is derived from various phthalates and is not necessarily all contamination since the peak at $\mathrm{m} / \mathrm{e} 279$ of composition $\mathrm{C}_{16} \mathrm{H}_{23} \mathrm{O}_{4}$ (Structure $\mathrm{XI}$ ) is too low in intensity. There are minor amounts of aromatic acid esters as for example, the series $\mathrm{C}_{\mathrm{n}} \mathrm{H}_{2 \mathrm{n}-8} \mathrm{O}_{2}$ for $\mathrm{n}=8$ to 12 and 14 to 16 (benzoic acids), $\mathrm{C}_{\mathrm{n}} \mathrm{H}_{2 \mathrm{n}-10} \mathrm{O}_{2}$ for $\mathrm{n}=12$ to 14 and $\mathrm{C}_{\mathrm{n}} \mathrm{H}_{2 \mathrm{n}-12} \mathrm{O}_{2}$ for $n=12$ to 15 . Small amounts of oxoacids of the series $\mathrm{C}_{n} \mathrm{H}_{2 n-2} \mathrm{O}_{3}$ are found $(\mathrm{n}=5$ to 8 and 12). The peak at $\mathrm{C}_{9} \mathrm{H}_{7} \mathrm{O}_{3}$ in the $\mathrm{C} / \mathrm{H} \mathrm{O}_{3}$ plot is derived from dimethyl phthalate and has the Structure XII.

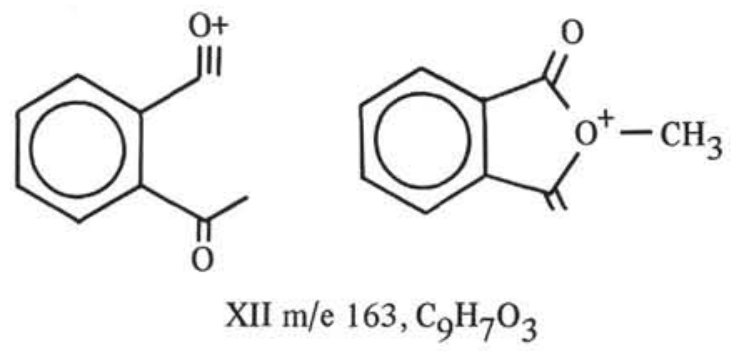

It belongs to the series $\mathrm{C}_{n} \mathrm{H}_{2 n-10} \mathrm{O}_{4}$ which is present for $n=10$ to 13 . The normal dicarboxylic acids of the series $\mathrm{C}_{\mathrm{n}} \mathrm{H}_{2 n-2} \mathrm{O}_{4}$ are present for $\mathrm{n}=5$ to 10 , as deduced from the $\mathrm{M}-\mathrm{CH}_{3} \mathrm{O}$ fragments $\left(\mathrm{C}_{\mathrm{n}} \mathrm{H}_{2 \mathrm{n}-3} \mathrm{O}_{3}\right)$. The $\mathrm{C} / \mathrm{H}$ plot of Figure 13 shows the ions of composition $\mathrm{C}_{18} \mathrm{H}_{23}, \mathrm{C}_{18} \mathrm{H}_{27}$ and $\mathrm{C}_{19} \mathrm{H}_{31}$ rather intense. Otherwise the pattern indicates the alkane chain fragmentation and the peak of composition $\mathrm{C}_{14} \mathrm{H}_{23}$ (Structure IV) is significantly above background.

The basic compounds separated from the methylene chloride extract were also analyzed by high resolution mass spectrometry and the data is shown in Figure 14. The small amount of sample only allowed this total mass spectral analysis. The compound series found are listed in Table 3. The series $\mathrm{C}_{n} \mathrm{H}_{2 n-5} \mathrm{~N}$ (pyridines) for $\mathrm{n}=6$ to $9, \mathrm{C}_{\mathrm{n}} \mathrm{H}_{2 \mathrm{n}-9} \mathrm{~N}$ (indoles) for $\mathrm{n}=8,9,13,14$ and 20 , and $\mathrm{C}_{\mathrm{n}} \mathrm{H}_{2 \mathrm{n}-11} \mathrm{~N}$ (quinolines) for $\mathrm{n}=9$ to 14 are the most abundant. The other series listed in Table 3 are found in minor amounts. The general distribution of these nitrogen compounds is analogous to that in the Green River Formation Oil Shale (Simoneit et al., 1970). Species of compositions $\mathrm{C} / \mathrm{H} \mathrm{N}_{2}, \mathrm{C} / \mathrm{H} \mathrm{N}_{3}, \mathrm{C} / \mathrm{H} \mathrm{N}_{4}$ and $\mathrm{C} / \mathrm{HNO}$ were not detected.
A general flow sheet for the extraction and fractionation of this core is given in Figure 15 (the fractions analyzed to date are so indicated). In order to isolate any organics entrapped or bound to the mineral matrix (for example, adipocere - insoluble fatty acid salts), the extracted core residue was treated with hydrochloric acid and then reextracted. The methylene chloride/heptane extract amounted to 15 milligrams and a subsequent ether extract yielded an additional 10.2 milligrams of more polar material. The breakdown of the methylene chloride/heptane extract is shown in Figure 15. Further work on these fractions is in progress.

\section{CONTAMINATION FROM SAMPLING BAGS}

The samples received for preliminary examination were packaged on board the Glomar Challenger in mylar film and new paint cans, and were sealed in smaller lots in the Kapak pouches for the organic examinations. A sample bag (Kapak pouches are made of scotchpak polyester film) was extracted with $3: 1$ benzene/ methanol yielding an extract of 2.1 milligrams after solvent removal. The bag weighed 13.07 grams and the area extracted was $280 \mathrm{~cm}^{2}$, thus the soluble organics amounted to $7.5 \mu \mathrm{g} / \mathrm{cm}^{2}$, rather significant. The high resolution mass spectral data is shown in Figure 16 and indicates that the extract consists mainly of fully saturated hydrocarbons. The main two series present are $\mathrm{C}_{n} \mathrm{H}_{2 n+2}$ and $\mathrm{C}_{n} \mathrm{H}_{2 n}$ for $\mathrm{n}=2$ to 25 , the lower homologs most likely being rearrangement fragments. The series $\mathrm{C}_{n} \mathrm{H}_{2 n-2}, \mathrm{C}_{n} \mathrm{H}_{2 n-4}$ and $\mathrm{C}_{n} \mathrm{H}_{2 n-6}$ for $\mathrm{n}=3$ to 22 are found in minor amounts. More aromatic series and fatty acids were not detected. Phthalate esters and mono-oxygenated compounds are found only in trace amounts. Contamination by phthalates is quite common and is usually from multiple sources. The organic contamination of the Apollo Lunar Sample program was monitored by these same techniques and the report by Simoneit and Flory (in press) covers the ubiquitous phthalates as well as other commonly encountered contaminants and their respective sources in detail.

In conclusion, this report has presented some preliminary results on the higher weight hydrocarbons and oxygen and nitrogen containing molecules isolated from the DSDP Cores. Further work is in progress to elucidate the structures of these interesting molecules as well as continuing the preliminary analytical survey.

\section{ACKNOWLEDGEMENTS}

We thank Sadalla Nassar and Ellen Scott for technical assistance and Martha Petrie for assistance with the high resolution mass spectral data. 


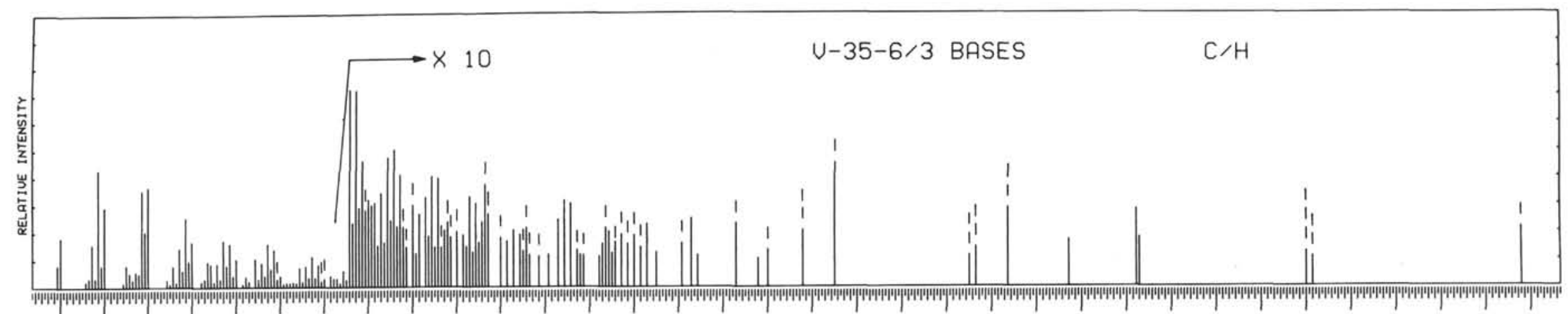

$2 / 53 / 74 / 95 / 116 / 137 / 15$ 8/17 9/19/0/2111/2312/2513/2714/2915/3116/3317/3518/3719/3920/4121/4322/4523/4724/4925/5126/5327/5528/5729/5930/6131/6332/6533/6734/6935/7

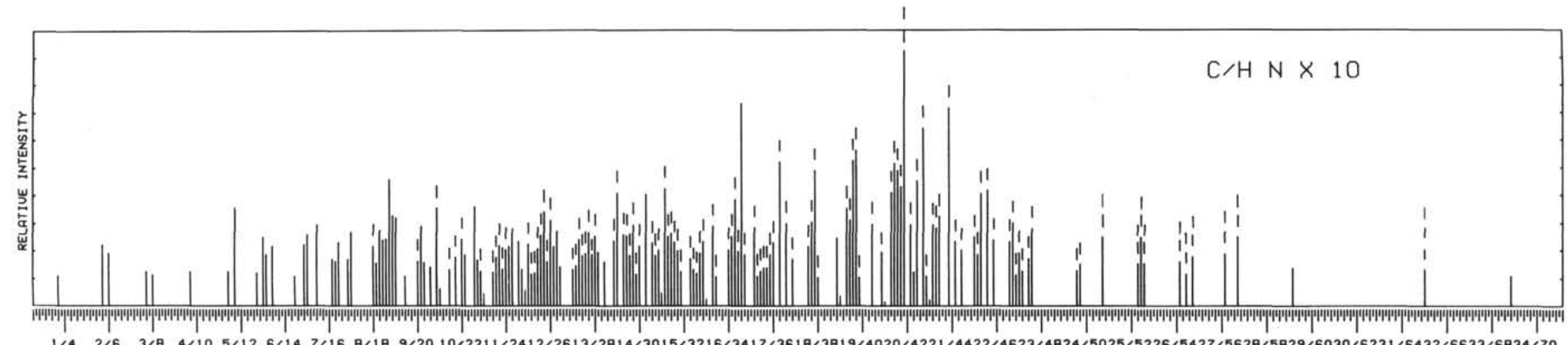

$1 / 4 \quad 2 / 6 \quad 3 / 8 \quad 4 / 105 / 126 / 147 / 16$ 8/1日 9/20 10/2211/2412/26/3/2814/3015/3216/3417/3618/3819/4020/4221/4422/4623/4824/5025/5226/5427/5628/5829/6030/6231/6432/6633/6834/70

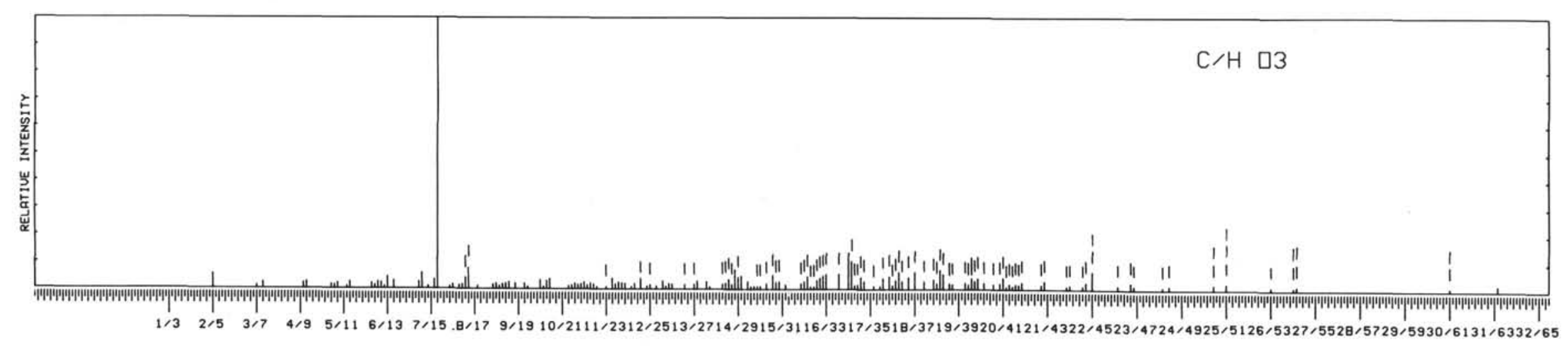

Figure 14. Partial summed high resolution mass spectral data for the bases derived from Leg 5, Core 35-6-3. 
TABLE 3

General Nitrogen Compound Distribution Found in the Base Extract of Core 35-6-3, Leg 5

\begin{tabular}{|c|c|c|c|}
\hline & Skeletal Examples & Series & $\mathrm{n}$ Found \\
\hline 1) & & $\mathrm{C}_{\mathrm{n}} \mathrm{H}_{2 \mathrm{n}-5^{\mathrm{N}}}$ & $6-9$ \\
\hline 2) & & $\mathrm{C}_{\mathrm{n}} \mathrm{H}_{2 \mathrm{n}-7^{-}} \mathrm{N}$ & $9,11+12$ \\
\hline 3) & & $\mathrm{C}_{\mathrm{n}} \mathrm{H}_{2 \mathrm{n}-9} \mathrm{~N}$ & $8,9,13,14+20$ \\
\hline 4) & & $\mathrm{C}_{\mathrm{n}} \mathrm{H}_{2 \mathrm{n}-11} \mathrm{~N}$ & $9-14$ \\
\hline 5) & & $\mathrm{C}_{\mathrm{n}} \mathrm{H}_{2 \mathrm{n}-13^{\mathrm{N}}}$ & $12 \cdot 15$ \\
\hline 6) & & $\mathrm{C}_{\mathrm{n}} \mathrm{H}_{2 \mathrm{n}-15^{\mathrm{N}}}$ & $12 \cdot 16$ \\
\hline 7) & & $\mathrm{C}_{\mathrm{n}} \mathrm{H}_{2 \mathrm{n}-17} \mathrm{~N}$ & $13 \cdot 18$ \\
\hline 8) & & $\mathrm{C}_{\mathrm{n}} \mathrm{H}_{2 \mathrm{n}-19^{\mathrm{N}}}$ & 15 \\
\hline
\end{tabular}






Figure 15. Flow Sheet for the Extractions of Leg 5, Core 35-6-3. 


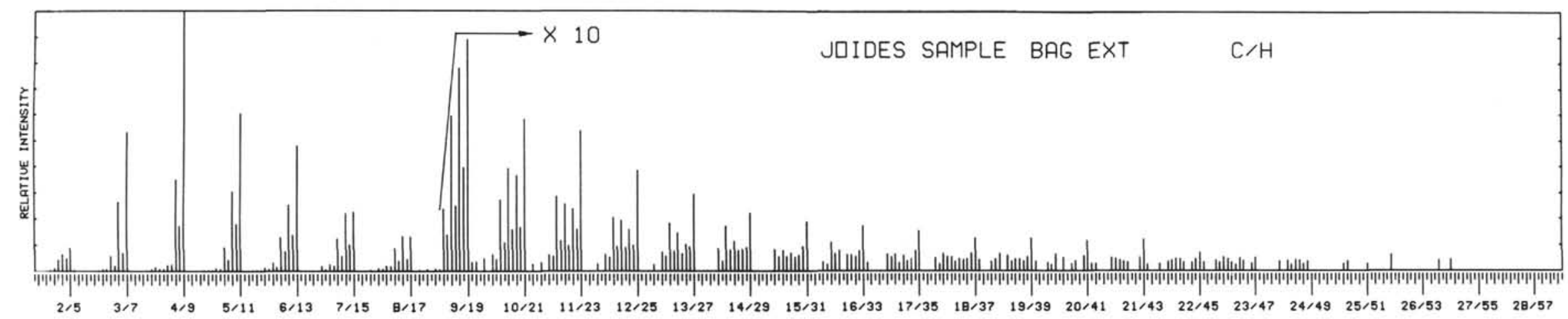

Figure 16. Partial summed high resolution mass spectral data for the extract from the Kapak sample pouches. 


\section{REFERENCES}

Burlingame, A. L., 1968. Data acquisition, processing and interpretation via coupled high speed real-time digital computer and high resolution mass spectrometer systems. Advances in Mass Spectrometry. E. Kendrick (Ed), London (The Institute of Petroleum), 4, 15.

Burlingame, A. L., 1971. Developments and applications of real-time high resolution mass spectrometry. Presented at the Intern. Conf. on Mass Spectroscopy, Kyoto, Sept. 8-12, 1969. Advances in Mass Spectrometry. $\mathbf{5}$, in press.

Burlingame, A. L., Haug, P. A., Schnoes, H. K., and Simoneit, B. R., 1969. Fatty acids derived from the Green River Formation Oil Shale by extractions and oxidations - a review. Advances in Organic Geochemistry 1968. P. A. Schenck and I. Havenaar (Eds.) Braunschweig (Pergamon - Viewig), 85.
Burlingame, A. L., and Smith, D. H., 1968. Automated heteroatomic plotting as an aid to the presentation and interpretation of high resolution mass spectral data. Tetrahedron. 24, 5749.

Burlingame, A. L., Smith, D. H., Merren, T. O., and Olsen, R. W., 1970. Real-time high resolution mass spectrometry. In Computers in Analytical Chemistry. C. H. Orr and J. Norris (Eds.), (Vol. 4 in Progress in Analytical Chemistry series), New York (Plenum Press), 17.

Simoneit, B. R., and Flory, D. A. In press. Apollo 11, 12 and 13 Organic Contamination Monitoring History. Proposed NASA Scientific Publication.

Simoneit, B. R., Schnoes, H. K., Haug, P. and Burlingame, A. L., 1970. Nitrogenous compounds of the Colorado Green River Formation Oil Shale: a preliminary analysis by mass spectrometry. Nature. 226, 75 . 